\title{
EFFECT OF STORAGE CONDITIONS ON THE QUALITY OF ONION BULBS
}

Hatem $^{1}$, M. H.; Shehata' ${ }^{2}$ S. A.; AbdEl-hay ${ }^{1}$, Y. B.; Karima ${ }^{2}$, F. AbdEl-Gwad and Abaker ${ }^{3}$, B. A.

\section{ABSTRACT}

Onion is one of the important commercial vegetable crops grown on a large scale in many countries. As the onion bulbs are to be stored for long period for use during off-season, a considerable loss occurs by way of deteriorating, sprouting, and moisture evaporation during storage. This study was conducted to investigate the effect of storage conditions on the quality parameters of onion bulbs, in objective to keep quality, reduce losses, prolong shelf life and keep the price stable and ensure uniform providing of the onion bulbs during the year. Three different storage conditions were used namely, forced ventilated, natural ventilated and traditional storage systems. The considered parameters of the onion bulbs those to be studied are moisture loss, deterioration, sprouting and marketable percentage. The environmental factors such as temperature and relative humidity were recorded during storage. The results indicated that, the average temperature in center of onion pile during the storage period ranged between 16.73 to $28.61{ }^{\circ} \mathrm{C}$ for the forced ventilated, where it was ranged between 18.18 to $31.03{ }^{\circ} \mathrm{C}$ for the natural ventilated, while in traditional storage system ranged between 19.52 to $32.93{ }^{\circ} \mathrm{C}$. The bulbs stored under natural ventilated system showed the lowest moisture loss $2.8 \mathrm{\%}$, and the lowest percentage of deterioration $6.55 \%$, while lowest percentage of sprouting was recorded for the forced ventilated and natural ventilated systems 1.47 and $1.52 \%$, respectively. The forced ventilated and natural ventilated storage systems recorded maximum marketable percentage (85.31 and $83.55 \%$ respectively), compared to traditional storage system $(81.51 \%)$. According to above results, natural ventilated with perforated pipes can be recommended for local community, which assure simplicity and easy to apply.

Keywords: storage systems, onion bulbs, temperature, relative humidity, forced ventilation, natural ventilation, traditional system, moisture losses, onion pile, deterioration, sprouting

\footnotetext{
${ }^{1}$ Agric. Eng. Dept., Fac. of Agric., Cairo University, Egypt

${ }^{2}$ Veg. Dept., Fac. of Agric., Cairo University, Egypt

${ }^{3}$ Agric. Eng. Dept., Fac. of Agric., Zalingei University, Sudan
} 


\section{INTRODUCTION}

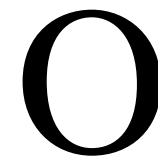
nion (Allium cepa 1.) is the bulb of the Alliaceae plant. Edible Alliums are important vegetables in terms of volume grown and world trade. In this respect, onion ranks a third after tomato and potato (Brewster, 1994).

In Egypt, the area under dry onion crop was 30323 feddan and the annual production was 410219 tones, the average yield was 13.528 t/fed during 2010-2011 (FAO STAT, 2011). Onion is a perishable crop; it cannot be stored safely in normal conditions for a long time. Presently, about $40 \%$ of the onion production is estimated to be lost during the post-harvest operations including handling and storage. Under all storage conditions, onion bulbs continuously loose water and dry matter, but more serious losses arise from storage rots, sprouting and rooting (Anonymous, 1994 and Pandey, 1989).

Deterioration of onion bulbs in storage is largely influenced by biological and environmental factors. Onion bulbs are living tissues which continuously undergo several metabolic processes, and, therefore, quantity and quality losses between harvest and consumption due to these processes may adversely affect bulb features (Kader, 1992).

Main factors which lead to deterioration of onion bulbs during storage are pre and post-harvest conditions and biological factors like respiration, resumption of growth and pathogen attacks. In Sudan, mud or straw cottage was used for storing onions. Straw cottage was constructed in such a way that, they were ventilated by the prevailing wind passing through them. After five months of storage by this method, $30 \%$ loss due to desiccation. The higher temperature of 30 and $35^{\circ} \mathrm{C}$ caused less sprouting but higher rotting and loss in weight was observed compared to lower temperature $\left(20-25^{\circ} \mathrm{C}\right)$ (Musa, et al., 1994). Ramin (1999) observed in cv. Grano and Dorcheh, sprouting was inhibited at high storage temperature $\left(25-30^{\circ} \mathrm{C}\right)$ as a result of significant reduction in the relative growth rate of sprout within the bulbs and onions become nearly dormant and maintained marketability for a period of three months. The moisture in food has a direct influence on its weight, and weight of 
material is related to its value in dollars. If the weight of fruit or vegetable in a packing house decreases by $5 \%$ due to moisture lost to the air, the owner has lost $5 \%$ of his product, which is $5 \%$ of gross income (Wilhelm et al., 2004).

Moisture and temperature are two important factors affecting rate of reaction in foods. Some of those reactions tend to degrade foods during storage. It is thus of major importance to know the temperature dependence of the rate of some reactions in order to predict product shelf life (Slade and Levine, 1991).

Onions can be stored at high temperatures of over $25^{\circ} \mathrm{C}$ at a range of relative humidity (75-85\%) which is necessary for minimizing water loss. However, weight loss, desiccation of bulbs and rots occurred at high temperatures, making the system uneconomic for long periods of storage that is required for successful onion marketing (Thompson et al., 1972).

In tropical climates, high-temperature storage of onions can be achieved under both ambient and heated storage conditions. Under these conditions, ventilation must be carefully applied inside the store to achieve the required temperature and humidity levels (Opara, 2003).

Ranpise et al. (2001) used the conventional onion storage structure called chawl which has no aeration at bottom, with resulting into lot of bruising and decay, and also reported onion stored in modified improved storage structure with bottom and central ventilation, reduced the storage losses from 99.2 to 70.0 per cent during five months storage.

Tripathi and Lawande (2003) reported that the total losses in low cost bottom ventilated structure are much lower $(35.17 \%)$ than recommended bottom ventilated structure $(44.96 \%)$, the sprouting and black mould infection was also lower in low cost storage structure, vary from location to location, and also with the type of farmers.

Straw cottage was constructed in such a way that, they were ventilated by the prevailing wind passing through them. The percentage of marketable bulbs were 50 to 60 After five months of storage by this method (Maini and Chakrabarti, 2000). 
Due to inadequate cold storage facilities to hold the produce for long periods, prices plunge at harvest time and large quantities are spoiled before they could be disposed off. Consumers are also unable to develop a habit of consuming more onions because onion stocks disappear from the market within a few months of harvest and by the end of the season onion prices jump very high. The main aims of this work is to study the effect of storage conditions on the quality of onion bulbs, so as to reduce losses, prolong shelf life and keep the price stable and ensure uniform providing of the onion bulbs during the year. Three different storage systems were used namely, forced ventilated, natural ventilated and traditional storage systems. Onion quality assessment was determined by studying weight loss, deterioration, sprouting and marketable percentages.

\section{EXPERIMENTAL PROCEDURES}

Onion bulbs c. v. of Giza 20 was produced at Waddy Elnatron Farm, Agricultural Experimental Station of the Faculty of Agriculture, Cairo University, according to the recommendations of standard agricultural practices during the winter seasons of 2012/2013. The crop was harvested on June 2013 when about $75-80 \%$ of the plants fall down and became matured. After harvest, bulbs were kept under a shade for 7 days in field and for other 7 days in shaded shelter for curing. Then, for storage studies, $600 \mathrm{~kg}$ bulbs were delivered to the Agricultural Engineering Department, Faculty of Agriculture Cairo University to store under different bins. The average moisture content of onion bulbs after harvest was $84 \pm 1.31 \%$.

\section{Storage bins}

The storage bins were designed to use local materials and to be simple to construct. It is an ordinary farm level storage bin made of wooden pole frame, woven wheat straw in wall, concrete floor covered with $10 \mathrm{~cm}$ straw above the floor and roof was covered with plywood to protect against rain and direct sunlight. The unit size is approximately $2 \mathrm{~m}$ long, $1.5 \mathrm{~m}$ wide and $3.0 \mathrm{~m}$ height as shown in figures 1 and 2 . 


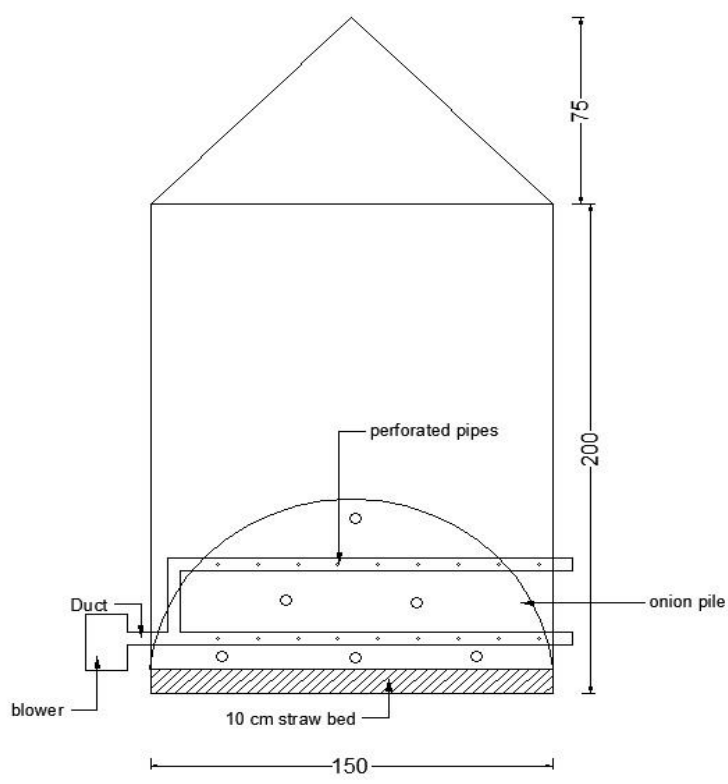

(A)

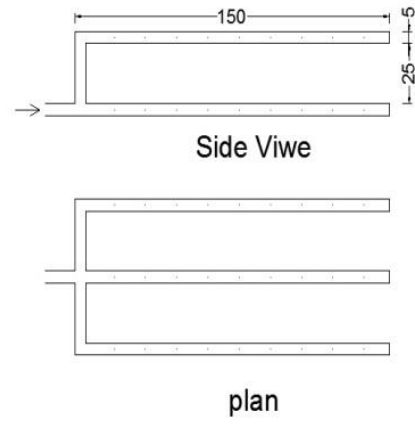

(B)

Figure 1: Diagram showing the ventilated system (A), chamber (B), onion pile and locations of sensors at forced ventilated system

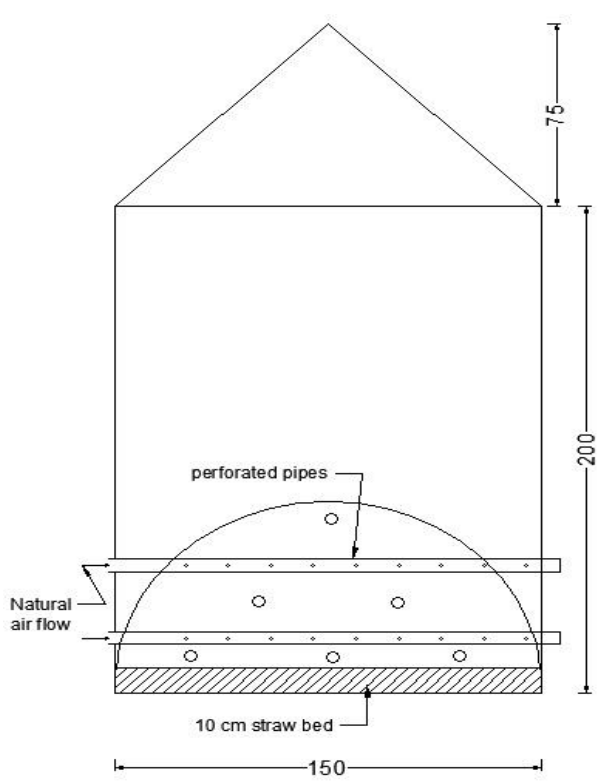

(C)

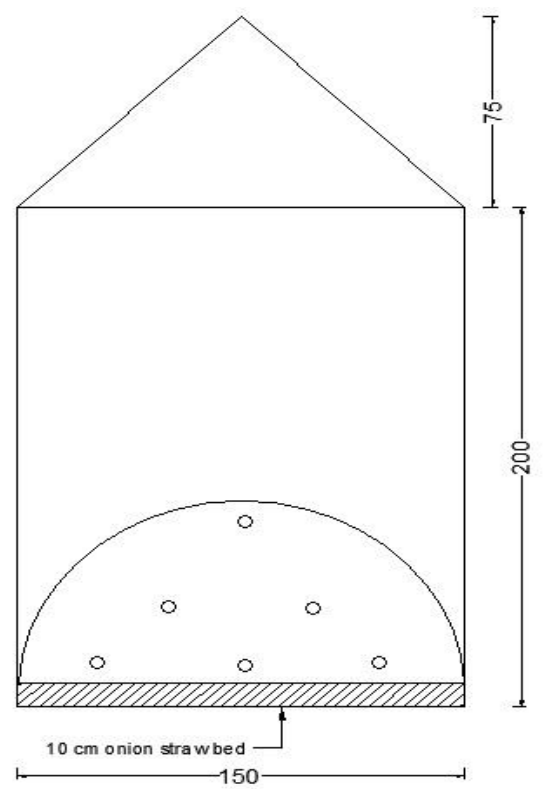

(D)

Figure 2 Diagrams showing the natural ventilated system (C), traditional system (D), onion pile and locations of sensors 


\section{Storage systems descriptions:-}

1- Forced ventilated system (with forced bottom ventilation), consists of low cost storage structure the top portion of structure was covered with conical shaped roof (thatched roof structures) with plywood; woven wheat straw in wall and the floor of the structures were covered with $10 \mathrm{~cm}$ onions straw as a bed. There was one door opened outside when required. The unit size, length, width and height were $2 \mathrm{~m} \times 1.5 \times 2.5 \mathrm{~m}$, respectively. This system consist of a blower (Milano centrifugal fan, model No. 130FLJ1, power $0.085 \mathrm{~kW}$, flow $216 \mathrm{~m}^{3} / \mathrm{h}$ ), was used to provide the ventilation air (delivering based on recommended fan sizes of $0.047 \mathrm{~m}^{3} \mathrm{~s}^{-1} \mathrm{t}^{-1}$ Electricity Council (1981)) measured by thermo-anemometer (model 407123 mode in Taiwan) located on the air supply pipe (50 mm diameter manifold) which distributes the air inside the onion pile through perforated laterals located at different depths 15, 25, and $40 \mathrm{~cm}$. The holes $(1 \mathrm{~cm}$ in diameter) were uniformity distributed on the laterals surface, 4 holes every $10 \mathrm{~cm}$ alternatively placed on the four sides of the pipe figure 1 .

2- Natural ventilated storage system, in this system the same frame, dimensions, pipes and depths as mentioned at forced ventilation were used, to distribute air naturally inside the onion pile through perforated holes so as to achieve a relatively stable temperature and RH within onion pile figure 2 .

3- Traditional storage system, this is a common used system of onion storage, to simulate this system the same frame and dimensions as mentioned before was used, without bottom ventilation and the onion was piled traditionally inside it figure 3.

Each storage system was filled with $600 \mathrm{~kg}$ cured bulbs (200 kg/treatment) which were stored directly on the floor of the storage structures. Each treatment was divided into three replications; the bulbs were stored for 8 months.

\section{Meteorological data}

During the period of experimentation, the daily temperature and relative humidity were recorded 4 times at 6:00 a. m., 12:00 noon, 6:00 p. m., and 12:00 a. m. at various locations in onion pile, storage structures and the ambient temperature by Data logger (Labjack U3-HV, ). 


\section{Measurements:}

\section{1- Moisture loss percentage}

The moisture loss in weight percentage was calculated using the formula given below:

$$
M L(\%)=\left[\frac{W_{o}-W_{n}}{W_{o}}\right] \times 100
$$

$$
\begin{array}{ll}
\text { Where, } & \mathrm{W}_{\mathrm{o}}=\text { Initial weight } \mathrm{kg} \\
& \mathrm{W}_{\mathrm{n}}=\text { Weight after } \mathrm{n} \text { days, } \mathrm{kg}
\end{array}
$$

\section{2- Deterioration percentage}

The deteriorating percentage on stipulated months after storage was determined by observing onion bulb showing symptoms of rotting, sprouting, and diseases were separated and weighed. The deteriorating percentage monthly was calculated by using the formula:

$$
\text { deterioration percentage }=\frac{\text { weight of the deteriorated bulbs }}{\text { initial weight of bulbs }} \times 100
$$

\section{3- Sprouting percentage}

For determination the sprouting percentage on stipulated days after storage, the bulbs showing a sprout were separated from the experimental lots and weighed on an electronic balance. The sprouting percentage which indicated the weight of bulb sprouted was calculated by using the formula:

$$
\text { Sprouting percentage }=\frac{\text { weight of the sprouting bulbs }}{\text { initial weight of bulbs }} \times 100
$$

\section{4- Marketable bulbs (\%)}

At the end of storage period (8months), the rotted, defected and shrinkage bulbs were separated and the weight of healthy bulbs was recorded. The recovery of marketable bulbs was calculated by using the following formula:-

$$
\text { Marketable bulbs }(\%)=\frac{\text { Weight of the healthy bulbs obtained }}{\text { Initial weight of bulbs stored }} \times 100
$$

\section{RESULTS AND DISCUSSION}

Onion quality parameters such as moisture loss, sprouting and deterioration percentage were determined for the onion stored under different storage conditions (forced ventilated, natural ventilated and traditional storage systems) . 


\section{1- Storage conditions:}

\section{a. Temperature:-}

Temperature and relative humidity were the most important environmental factors that affect the onion bulbs during storage. Figure (3) shows the average temperature of the different onion storage systems compared with the ambient temperature during the storage period from July to February. It could be seen that the average temperature changed from 31.35 to $17.45{ }^{\circ} \mathrm{C}$ for the forced ventilated storage system, while, it changed from 33.07 to $18.96{ }^{\circ} \mathrm{C}$ for the natural ventilated storage system. On the other, the traditional storage system temperature changed from 34.97 to $18.68{ }^{\circ} \mathrm{C}$ compared to 30.4 to $10.1{ }^{\circ} \mathrm{C}$ for the ambient temperature.

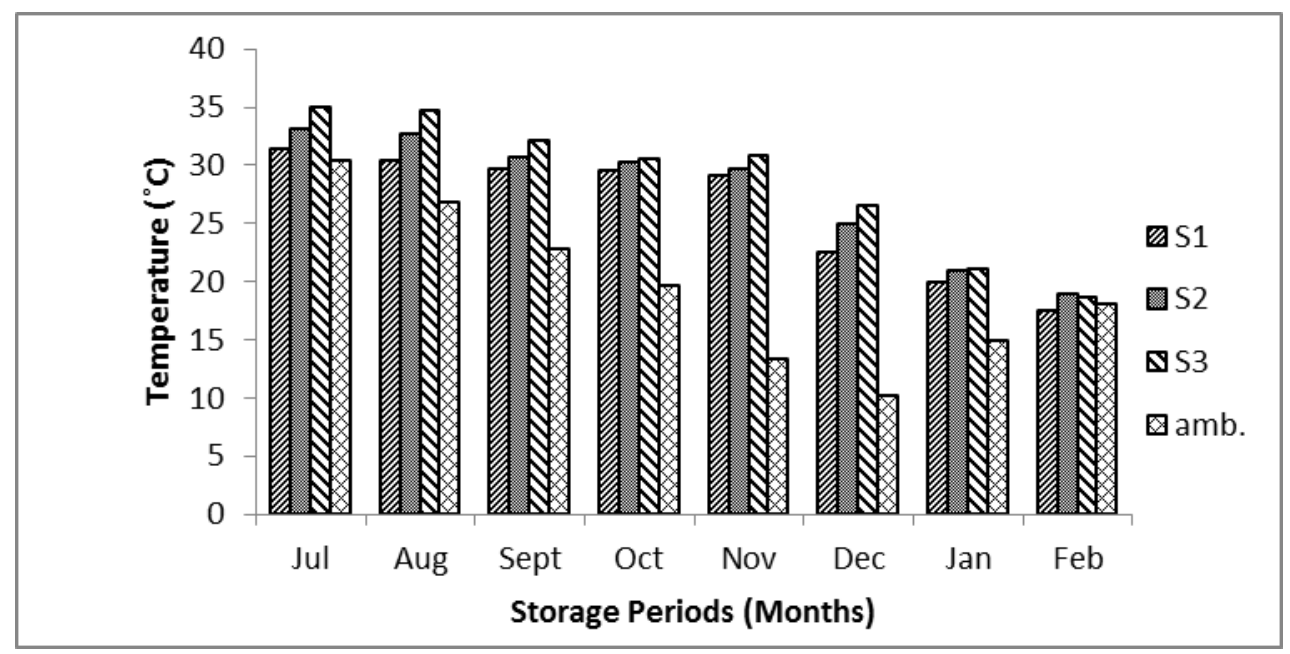

Figure 3: Temperature variation at the center of onion pile during the storage periods under forced ventilated (S1), natural ventilated (S2), traditional storage system (S3) and ambient condition $\left(\mathrm{T}_{\mathrm{amb}}\right.$.).

\section{b. Relative humidity:-}

Figure (4) shows the average relative humidity inside the different onion storage systems under study compared to the ambient relative humidity. The figure shows that, relative humidity decreased from 70.89 to $64.25 \%$ for the forced ventilated storage system, where it was changed from 75.1 to $65.55 \%$ for the natural ventilated storage system. While, in traditional storage system relative humidity changed from 77.14 to $67.05 \%$ compared to 68 to $57 \%$ for the ambient temperature. 


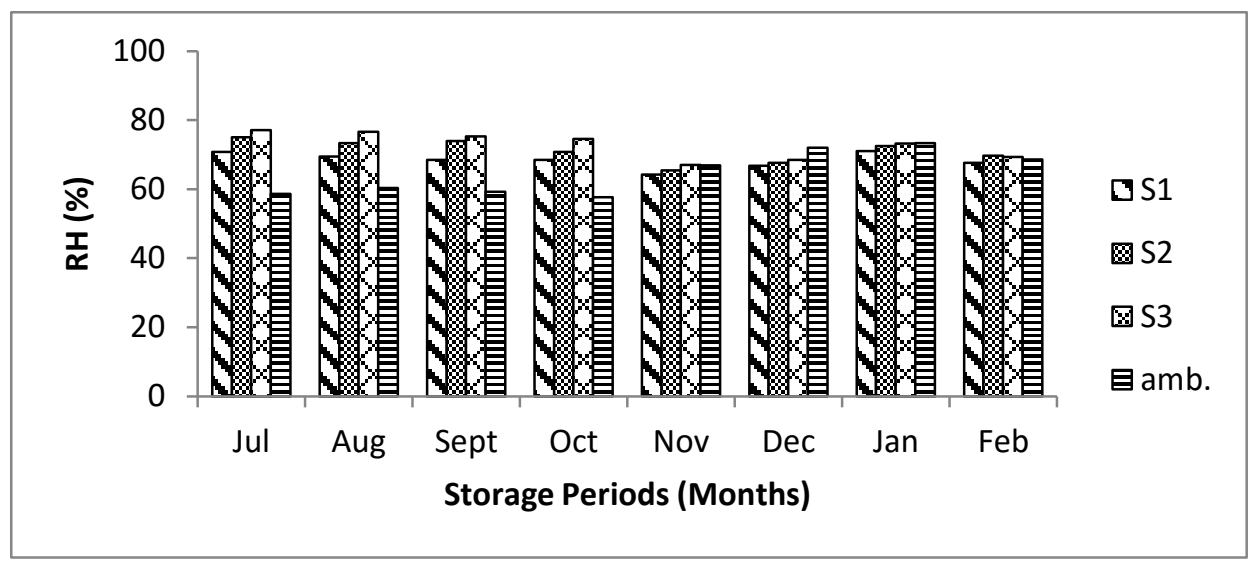

Figure 4: Relative humidity variations at the center of onion pile during the storage periods under forced ventilated (S1), natural ventilated (S2), traditional storage system $(\mathrm{S} 3)$ and ambient condition $\left(\mathrm{RH}_{\mathrm{amb}}\right)$.

\section{2- Onion quality:}

\section{2-1 Onion moisture loss:}

Moisture loss is usually known to occur due to dehydration, transpiration, respiration, rotting, sprouting, etc. and it is generally caused due to prevailing high temperature and low humidity in the environment. It has been observed that although high humidity effectively reduced weight loss, it favoured fungal development, especially at higher temperature (Shippers, 1968).

Data in Figure 5 revealed the effect of different storage systems (forced ventilated, natural ventilated and traditional storage system) on the moisture loss of onion bulbs during seven months of storage periods. The mean percentages of accumulation moisture losses were 12.01, 12.2 and $14.65 \%$ for the onion stored under forced ventilated, natural ventilated and traditional storage system, respectively. The results also revealed that, the moisture losses of onion bulbs after the first month of storage were 2.190, 2.450 and $2.713 \%$ for the same previous order, respectively. While the moisture loss percentage at the last month of storage periods were $2.653,3.247$ and $3.513 \%$ for the onion stored under natural ventilated, forced ventilated and traditional storage systems, respectively. 
Forced ventilated and natural ventilated system, recorded the lowest moisture loss percentage which was probably due to less transpiration and respiration due to low temperature and high relative humidity as presented in Figures 3, 4, and as a result of reaching equilibrium in relative humidity between the air and onion pile. In comparison with the results of Jamali, et al. (2012) who found that, overall physiological weight loss after 60 days of storage was $7.74 \%$ in Nassarpuri cv., $8.86 \%$ in Phulkara cv. and Indian bulbs gave maximum loss in weight $10.89 \%$.

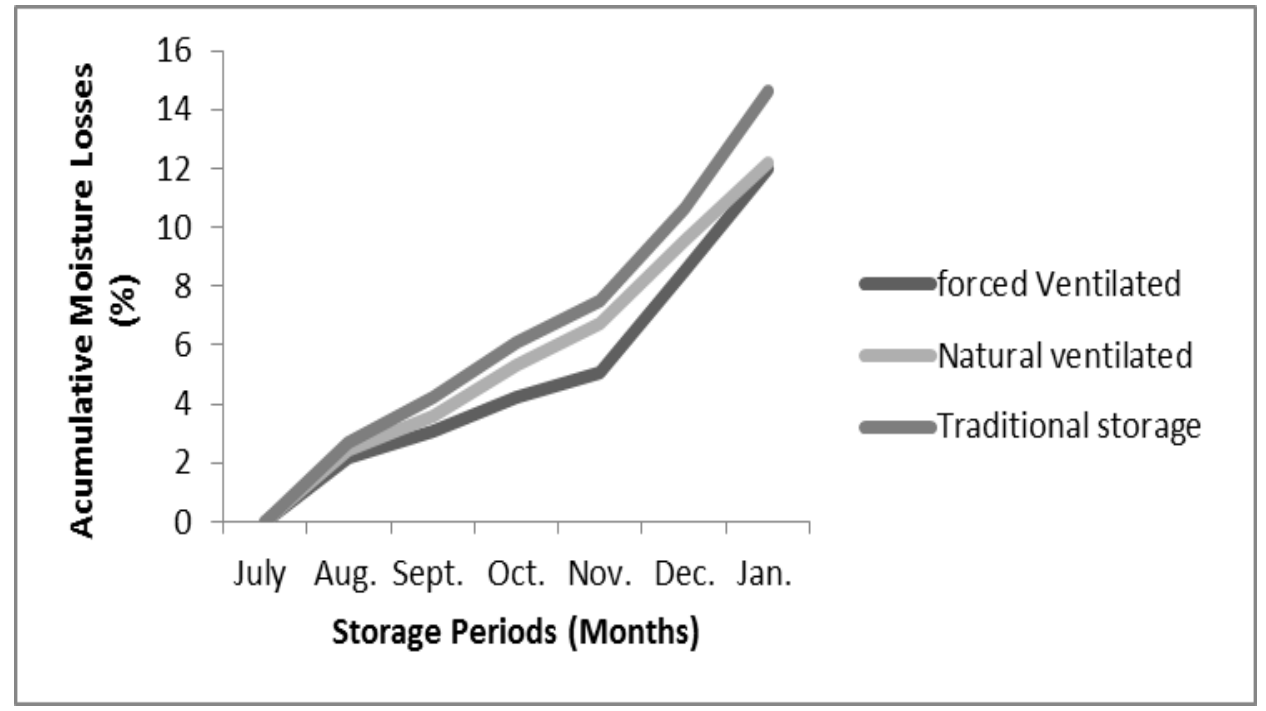

Figure 5: Accumulative moisture losses percentage of onion stored under forced ventilated, natural ventilated and traditional storage systems.

Also the moisture loss increased with the advancement of storage period. This result agrees with that found by Gubb and Mac-Tavish, (2002) who reported that, the weight loss of bulbs ranged from 2 to $5 \%$ of fresh weight/ month during the first month of storage depend on the cultivar. The general trend, however, high rate of physiological weight loss within the first month, possibly due to transpiration through the dermal system, and the neck and stem regions, before completely sealing to reduce rate of moisture loss at storage. These results have been elucidated by Kader (1992) and Brewster (1994). 
The moisture loss during the first four months of storage was due to the prevailing of high temperature according to the metrological data measured during this periods as shown in Figures 3 and 4, and the positive correlation between temperature and moisture loss percentage $r^{2}=0.93$, while the highest moisture loss during the remain months of storage as a result of deterioration and sprouting as appeared in Figures 6 and 7. The results are supported by Maw, et al., (2005) who found that weight loss varied from an average of $4 \%$ for cold storage, to $6 \%$ for controlled atmosphere storage, and $54 \%$ for the low humidity and warm air storage as based upon the original weight of onions placed in storage.

Regression analysis was carried out to find a relationship between the moisture losses (ML) as a function of storage period (t, 1-8 months) under different storage systems. The most appropriate forms were as follows:

$$
\begin{array}{lll}
\mathrm{ML}=0.7521(\mathrm{t})-1.9146 & \left(\mathrm{R}^{2}=0.770\right) & \text { for forced ventilated system } \\
\mathrm{ML}=0.8011(\mathrm{t})-2.0883 & \left(\mathrm{R}^{2}=0.732\right) & \text { for natural ventilated system } \\
\mathrm{ML}=0.9314(\mathrm{t})-2.3862 & \left(\mathrm{R}^{2}=0.754\right) & \text { for traditional system }
\end{array}
$$

\section{2-2 Onion deterioration:}

The main factors which cause onion deterioration during storage are pre and postharvest conditions and biological factors like respiration, resumption of growth and pathogen attacks.

Figure 6 shows the deterioration percentage of onion bulbs stored under the three types of storage systems (forced ventilated, natural ventilated and traditional storage systems). Initially, there was there was no deterioration up to the third month of storage. The mean percentages of deterioration were $0.813,1.934$ and $2.802 \%$ for the onion stored under forced ventilated, natural ventilated and traditional storage system, respectively. The results also revealed that, the deterioration percentages at the last month of storage periods were $3.87,7.73$ and $10.04 \%$ for the same previous order, respectively. Also, there were a positive correlation between temperature and deterioration $r^{2}=$ 0.987 . 


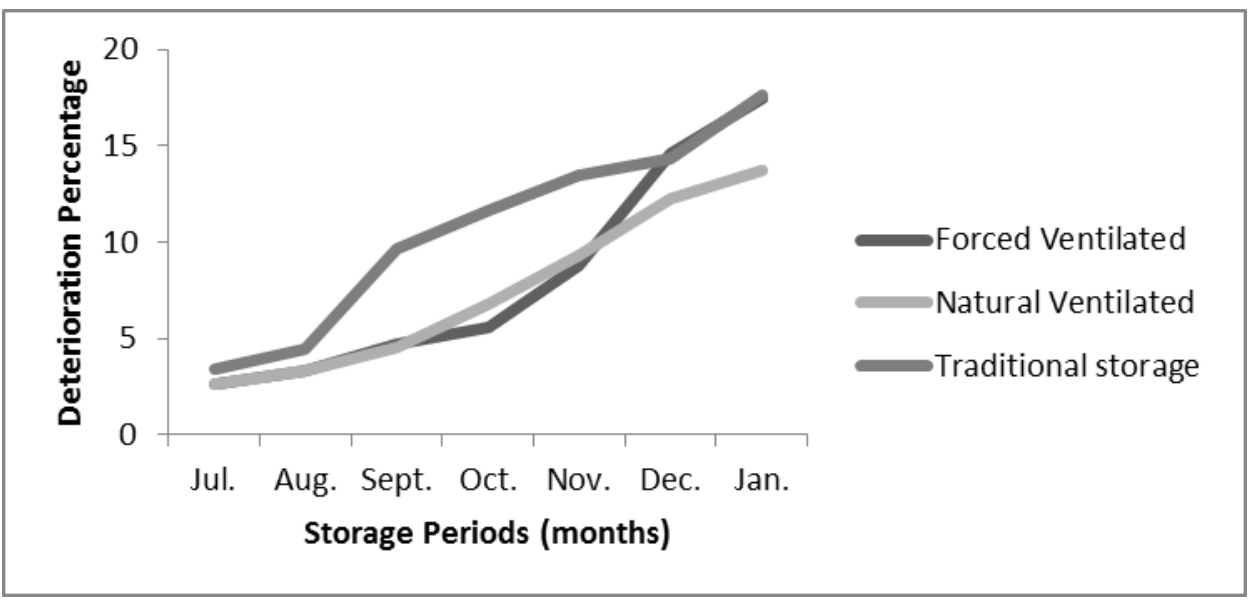

Figure 6 Deterioration percentages of onion bulbs stored under forced ventilated, natural ventilated and traditional storage systems.

The highest deterioration percentage in traditional storage system may due to high temperature and relative humidity compared to the other systems as shown in Figures 3 and 4. These results in line with the results of Bangiwar and Shirsat, (2000), and Chavan et al. (1997), who found that, due to the buildup of respiratory heat and humidity within the onion pile creating favourable conditions for the proliferation of the spoilage pathogens.

With respect to the percent of deterioration during all the stages of storage period, the lowest deterioration and black mould was observed in natural ventilated storage and forced ventilated, this may be due to proper ventilation as well as minimum fluctuation in storage temperature. In compare with the results of Maw, et al., (2005) that, with shrinkage by volume, under low humidity, warm air storage a corresponding total loss of weight was noted, being approximately 29, 36 and $40 \%$ for successive treatments of onions having a 10, 15 and $20 \%$ contamination, respectively. These results also confirm with finding of Aoyagi et al., (1997) who described that, decay of bulbs is increased with increase in temperature and storage period.

Regression analysis was carried out to find a relationship between the deterioration of onion bulbs (D) as a function of storage period (t, 1-8 months) under different storage systems. The most appropriate forms were as follows: $\begin{array}{lll}\mathrm{D}=2.3775(\mathrm{t})-3.5812 & \left(\mathrm{R}^{2}=0.913\right) & \text { for forced ventilated system } \\ \mathrm{D}=1.9548(\mathrm{t})-2.2471 & \left(\mathrm{R}^{2}=0.977\right) & \text { for natural ventilated system }\end{array}$ 
$\mathrm{D}=2.4649(\mathrm{t})-1.7936 \quad\left(\mathrm{R}^{2}=0.973\right) \quad$ for traditional system

\section{2-3 Onion sprouting:}

A glance of the results presented in Figure 7 revealed that there was no sprouting up to the fifth month of storage, in all the tested treatments (forced ventilated, natural ventilated and traditional storage systems). These results might be due to the onion dormancy and higher temperature at these periods of storage. The results of metrological data revealed that mean ambient temperature of stored onion bulbs remained between 34.97 to $29.05{ }^{\circ} \mathrm{C}$ during this period. These results are supported by Jamali, (2012) who find that, high temperature of $35^{\circ} \mathrm{C} \pm 2{ }^{\circ} \mathrm{C}$ and relative humidity in onion bulbs store was mostly below $75 \%$, therefore sprouting, rotting and fungus attack could not develop in stored onion bulbs under these conditions. The mean sprouting percent of the bulbs were $0.34,0.48$ and $0.63 \%$ for the forced ventilated, natural ventilated and traditional storage systems. The highest sprouting percentage was recorded at last month of storage $2.39,3.39$ and $3.88 \%$, for the same previous order, respectively.

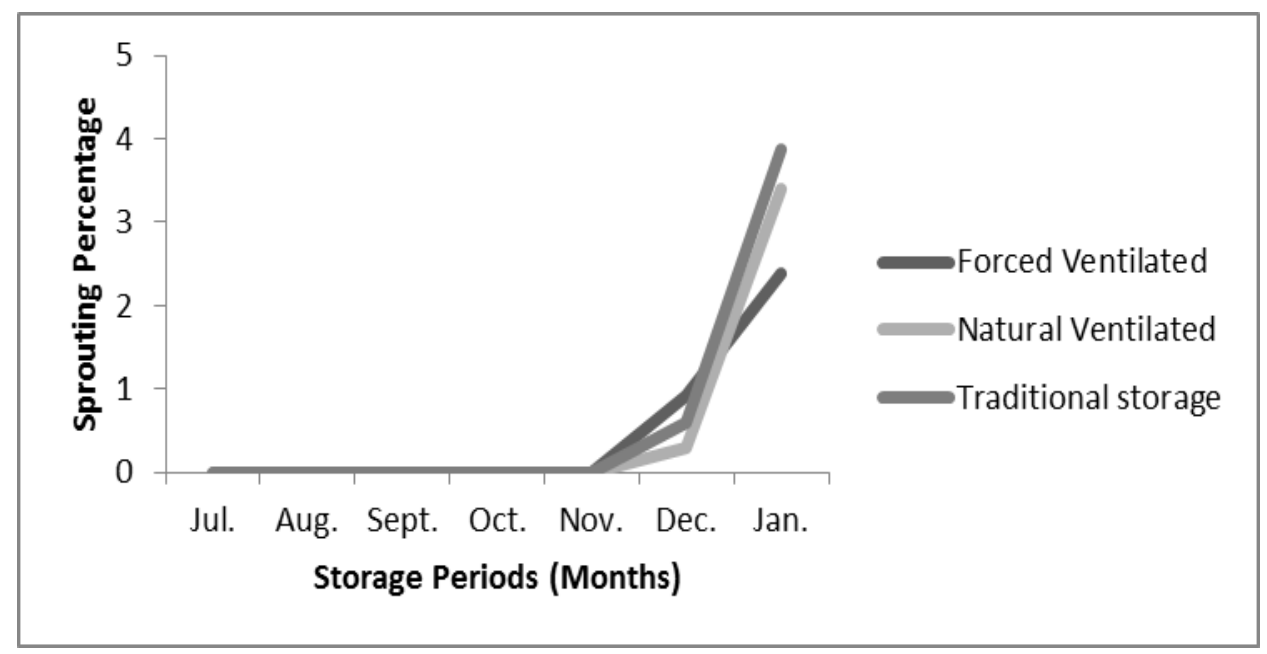

Figure 7 Sprouting percentages of onion bulbs stored under forced ventilated, natural ventilated and traditional storage systems.

The highest percentage of sprouting in traditional storage system $(3.88 \%)$ may be due to poor ventilation which could result in the build-up or humidity pockets within the onion pile and help to promote sprouting and also sustain 
the continued more vigorous growth of these sprouts. This result is in line with the findings of Bongiwar and Shirsat (2000). Also might be due to low ambient temperature during this period and reduction of the accumulation of humidity within onion pile, this confirm with finding of Va'zquez-Barrios, et al., (2006) who found that, there was more sprouting in onions stored at 10 and $15{ }^{\circ} \mathrm{C}$ than at low $\left(0{ }^{\circ} \mathrm{C}\right)$ or high $\left(40{ }^{\circ} \mathrm{C}\right)$ temperatures., in addition to higher deterioration of bulbs during this periods as mentioned in Figure 6.

The lowest sprouting percentages were recorded in forced ventilation, these results were attributed to the low relative humidity reduced sprouting and also better air movement amongst bulbs pile under these methods of storage which probably reduced the sprout percentage and prolongs the dormancy period. This confirms the mention of Thompson et al., (1972) that the onion bulbs are naturally dormant at maturity and the length of this dormant period varies with the cultivar and conditions under which the bulbs were grown and stored. Salunkhe and Desai (1984) described sprouting as a normal physiological change in stored bulbs that develops reproductive shoots.

Regression analysis was carried out to find a relationship between the sprouting percentages ( $\mathrm{S}$ ) as a function of storage period (t, 1-8 months) under different storage systems. The most appropriate forms were as follows:

$$
\begin{array}{lll}
S=0.7521(t)-1.9146 & \left(R^{2}=0.770\right) & \text { for forced ventilated } \\
S=0.8011(t)-2.0883 & \left(R^{2}=0.732\right) & \text { for natural ventilated } \\
S=0.9314(t)-2.3862 & \left(R^{2}=0.754\right) & \text { for traditional system }
\end{array}
$$

\subsection{The marketable onion bulbs:-}

Data in Table 1 shows marketable percentage of onion bulbs during storage for seven months under three different storage systems (forced ventilated, natural ventilated and traditional systems), and the mean of marketable bulbs recorded $85.31,83.55$ and $81.51 \%$ for the onion stored under forced ventilated, natural ventilated and traditional systems, respectively. While the marketable percentage decreased by increasing of storage periods and it reached the lowest 
percentage $(72.35,70.36$ and $66.07 \%$, respectively) by the end of storage for the same previous order of systems, respectively.

Table 1: The marketable onion bulbs:-

\begin{tabular}{|c|c|c|c|c|c|c|c|c|}
\hline \multirow[t]{3}{*}{ Storage systems } & \multicolumn{7}{|c|}{ Marketable onion \% } & \multirow[t]{3}{*}{ Means } \\
\hline & \multicolumn{7}{|c|}{ Storage periods } & \\
\hline & Jul. & Aug. & Sept. & Oct. & Nov. & Dec. & Jan. & \\
\hline Forced ventilated & 100.0 & 94.99 & 89.98 & 84.96 & 79.94 & 74.97 & 72.35 & 85.31 \\
\hline Natural ventilated & 100.0 & 94.66 & 88.64 & 81.30 & 77.28 & 72.63 & 70.36 & 83.55 \\
\hline Traditional storage & 100.0 & 92.66 & 87.63 & 79.29 & 73.96 & 70.99 & 66.07 & 81.51 \\
\hline Means & 100.0 & 94.10 & 88.75 & 81.85 & 77.06 & 72.86 & 69.59 & \\
\hline LSD at 0.05 & \multicolumn{8}{|c|}{$\begin{array}{ll}\text { For treatment } & =1.478 \\
\text { For storage periods } & =1.812 \\
\text { For interaction } & =1.046\end{array}$} \\
\hline
\end{tabular}

\section{CONCLUSION}

The quality of onion as affected by different storage conditions was studied and the obtained results could be concluded as follows:

1- The average temperature inside the different onion storage systems compared with the ambient temperature during the storage period ranged between 31.35 to $17.45{ }^{\circ} \mathrm{C}$ for the forced ventilated storage system, where it was ranged between 33.07 to $18.96{ }^{\circ} \mathrm{C}$ for the natural ventilated storage system. While, in traditional storage system temperature ranged between 34.97 to $18.68{ }^{\circ} \mathrm{C}$, compared to 30.4 to $10.1{ }^{\circ} \mathrm{C}$ for the ambient temperature

2- The average relative humidity ranged between 70.89 to $64.25 \%$ for the forced ventilated system, where it was ranged between 75.1 to $65.55 \%$ for the natural ventilated system. While, in traditional system temperature ranged between 77.14 to $67.05 \%$ compared to 68 to $57 \%$ for the ambient RH.

3 - The lowest moisture loss was recorded in natural ventilated system $2.83 \%$, while the lowest accumulation moisture losses percentages 12.01 and $12.2 \%$ were recorded at forced ventilated and natural ventilated systems, respectively. 4- The bulbs stored under natural ventilated system showed lowest percentage of deterioration $6.55 \%$.

5- While lowest percentage of sprouting 1.47 and 1.52\% was recorded at forced ventilated and natural ventilated systems, respectively.

6- The lowest mean percentage of marketable bulbs $81.51 \%$ was recorded at traditional storage system. 
According to above results, natural ventilation with perforated pipes can be recommended for local community.

\section{REFERENCES}

Anonymous (1994). Post-harvest losses, Research Digest, AICRP on PostHarvest Technology (1980-90), Gujarat Agric. University, Junagadh, India. p. 9.

Aoyagi, M.; Makino, H. and Sato, J. (1997). The effect of storage temperature on keeping quality of onion bulbs. Research Bulletin Aichiken, 9: 54-60.

Bongiwar, D.R. and Shirsat, S.G. (2000). Demonstration food irradiation facilities for prevention of losses due to sprouting in onion and garlic by use of gamma radiation at Lasalgoan in maharashtra. National Research Centre for Onion and Garlic, Rajgurunagar, Nasik, pp. 32-36.

Brewster, J.L. (1994). Onions and Other Vegetable Alliums. Wallingford, UN: CAB International.

Chavan, V.B.; Dsouza, T.F. and Rajeshkumar, A. (1997). Evaluation of different structures for storage of onions. Vegetable Science, 24(1): 73-74.

Electricity Council (1981). Vegetable conditioning and storage- onion. Technical information AGR 8-2.

FAOSTAT (2011). Food and agricultural organization of the united nations, statistical database (www.faostat.es). Agricultural production. Postharvest treatment

Gubb, I.R and Tavish, H.S.M. (2002). Allium crop science, Recent Advance ed. by Ravinowitch, H.D and Currah, L. 10 Onion Pre and Post-harvest considerations, walling ford Oxon: CABI Publishing. pp.233-265.

Jamali, L. A.; Ibupotp, K. A.; Chattha, S. H. and Laghari, R. B. (2012). Study on physiological weight loss in onion varieties during storage. Pak. J. Agri., Agri. Engg., Vet. Sci., 28 (1): 1-7.

Kader, A. A. (1992). Postharvest biology and technology: An overview. In Postharvest Technology of Horticultural Crops. Publication 3311. Pp.15-37. University of California, Division of Agric. and Natural Resources.

Maini, S.B. and Chakrabarti, A.K. (2000). Postharvest management of onions and garlic. Souvenir, National Symposium on Onion and Garlic Production and 
Postharvest Management: Challenges and Strategies, 19-21 Nov.2000, National Research Centre for Onion and Garlic, Rajgurunagar, Nasik, pp. 25-32.

Maw, B. W.; Seebold, K. W.; Purvis, A. C. and Paulk, J. T. (2005). Low humidity, warm air storage effective for medium-term storage of sweet onions. American Society of Agricultural Engineers, 21(2): 259-264.

Musa, S.K.; Abdalla, Y.M.; Haimoura, E. and Suliman, Y. (1994). Improvement of onion storage in the Sudan. Tropical Sciences, 34(2): 185-190.

Opara, L. U. (2003). Chapter XXVI Onions: Post-Harvest Operation, Mejia D, Parrucci E, (eds) Compendium on Post-Harvest Operations, FAO Information Network on Postharvest Operations, http://www.fao.org/inpho/

Pandey, U.B. (1989). Problems in post-harvest handling of onion and current status of research work done by AADF in the field of post-harvest technology. Associated Agric. Develop. Foundation, Nasik. Newsletter No. 3 \& 4, Vol. 9.

Ramin, A. A. (1999). Storage potential of bulb onion under high temperature. Journal of Horticultural Sciences and Biotechnology, 74(2): 181-186.

Ranpise, S.A.; Birade, R.M.; Patil, B.T. and Sawant, S.V. (2001). Factors affecting the storage of onion: A Review. The Orissa Journal of Horticulture, 29(1): 1-12.

Salunkhi, D.K. and Desai, B.B. (1984). Postharvest biotechnology of vegetables. Vol. II., CRC Press, Inc. Boca Raton, Florida. pp. 23-34.

Shippers, P.A. (1968). A preliminary experiment for weight loss in onions. N.Z. Comm. Grow. 23(10): 23-29.

Slade, L. and Levine, H. (1991). Beyond water activity: recent advances based on an alternative approach to the assessment of food quality and safety. CRC Critical Reviews on food science and nutrition, 30:115-360.

Thampson , A.K.; Booth, R.H. and Proctor, F.J. (1972). Onion storage in tropics. Tropical Sciences, 14(1): 19-34.

Tripathi, P.C. and Lawande, K.E. ( 2003). Onion storage structure for small and marginal farmers. ICAR News, A Science and Technology Newsletter, 9(4): 18-19.

Va'zquez-Barrios; M.E. Lo'pez-Echevarrı'a; G. Mercado-Silva; E. CastañTostado; E. Leo'n-Gonza'lez, F. (2006). Study and prediction of quality 


\section{PROCESS ENGINEERING}

changes in garlic cv. Perla (Allium sativum L.) stored at different temperatures. Scientia Horticulturae, 108 : 127-132

Wilhelm, L.R.; Dwayne A. S. and Gerald H. B. (2004). Physical Properties of Food Materials. Chapter 2 in Food \& Process Engineering Technology, 23-52. St. Joseph, Michigan: ASAE. C American Society of Agricultural Engineers. (Rev. Aug. 2005).

\section{الملخص العربي}

\section{ثأثيز ظروف التخزين على جودة البصل}

\section{محمد هاشم حاتم' ، سعيد عبدالله شحاته'، يسري بيومي عبدالحي'، كريمة فاروق باديك

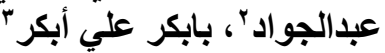

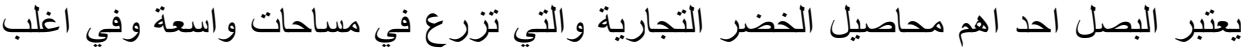

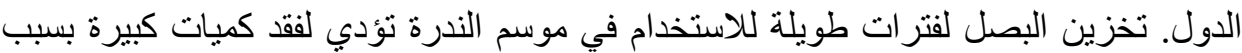
التدهور و التزريع وفقد الرطوبة. أجريت هذه التجربة لبحث اثر ظروف التخدين التخزين على معايير

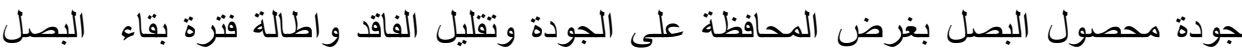
طازجاً و المحافظة علي استقرار اسعار البصل وضمان نوفيره خلادل السنة. تم استخدام ثلاثنة أنظمة تخزين مختلفة وهي نظام التخزين التقليدي و النظام المهو اه طبيعياً و النظام المهو اه فصرياً. ومعايير جودة البصل التي تم دراستها هي فقد الرطوبة والتدهور والتزريع ونسبة البصل القابلة

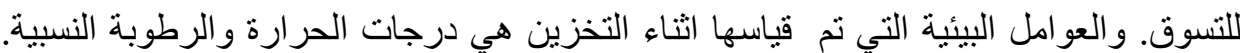
و أظهرت النتائج أن متوسط درجات الحرارة في وسط الكومة اثناء التخزين تراوحت فئ بين

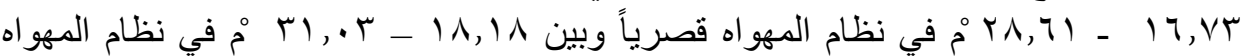

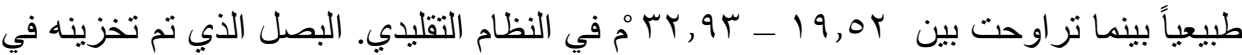

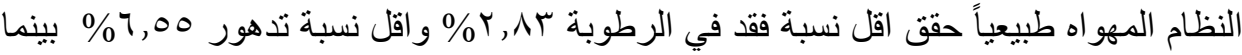

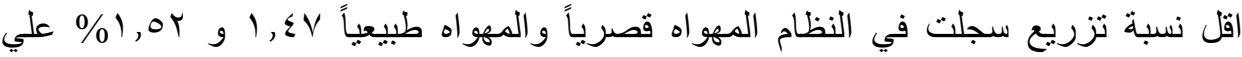

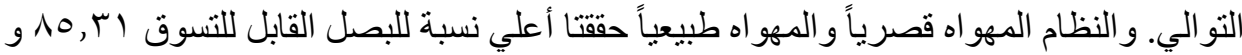

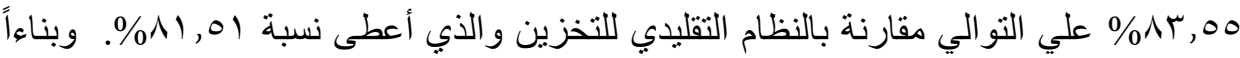
علي النتائج اعلاه يوصي بإستخدام النظام المهو اه طبيعياً للمجتمع المحلي وذلك لبساطتة وسئة اعهولة تطبيقه.

الكلمات الدالة: البصل، درجات الحرارة ، الرطوبة النسبية، تهوية طبيعية، تهوية قصرية، نظام تقليدي، فقد الرطوبة ، كومة البصل أنظمة التخزين، التذهور، التزريع.

ا قسم الهندسة الزراعية ـ كلية الزراعة ـ جامعة القاهرة.

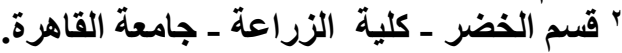

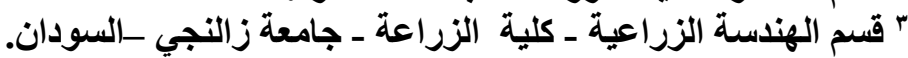

